\title{
Evaluation of PGPR Isolates for the Management of Beans Wilt Caused by Fusarium oxysporum f. sp. phaseoli
}

\author{
Stanzin Dorjey $^{1 *}$, T.A. Shah ${ }^{1}$, N.A. Bhat ${ }^{1}$, P.A. Sofi ${ }^{2}$, Z.A. Baba ${ }^{3}$ and M.A. Chatoo ${ }^{4}$ \\ ${ }^{1}$ Division of Plant Pathology, ${ }^{2}$ Division of Genetics and Plant Breeding, ${ }^{3}$ Division of RRS, \\ ${ }^{4}$ Division of Vegetable Science, Faculty of Agriculture, Sher-e-Kashmir University of \\ Agricultural Sciences and Technology, Wadura Sopore-193201, India \\ *Corresponding author
}

\begin{abstract}
A B S T R A C T
Fungal pathogen $F$. oxysporum (Schlecht.) f. sp. phaseoli Kendrick and Synder was isolated from the infected roots of bean plants. Microscopic examination revealed that the mycelium was septate which produced microconidia and macroconidia. The pathogen was accordingly identified after comparing with that of the standard texts. A total number of 24 rhizobacterial were isolated from the rhizosphere of different crops. Morphological studies revealed that out of 24 rhizobacterial isolates 9 showed light green, 2 green, 8 cream, 4 white and 1 red colour, 12 were round, non-spreading type whereas, 12 were irregular and spreading type colonies. Among all the rhizobacterial strains, 14 strains showed Gram -ve reaction, whereas, 10 rhizobacterial strains showed Gram +ve reaction. Out of the 24 isolates, 17 were small rods, whereas, 7 isolates were large rods. Under in vitro conditions, among 24 isolates 5 exhibited potential of acting as biocontrol agents in which isolate I-5 exhibited minimum radial growth $(28.00 \mathrm{~mm})$, resulting in inhibition of by $68.89 \%$ over control followed by isolate I-21 recorded radial growth of $29.63 \mathrm{~mm}$, thereby inhibiting the growth of pathogen by $67.08 \%$ over control. Among all the five selected PGPR isolates and carbendazim treated with beans seed showed minimum disease incidence and disease intensity compared to control. The seed treatment with carbendazim recorded minimum disease incidence $(3.12 \%)$ and disease intensity $(0.83 \%)$, followed by seed treatment with Stenotrophomonas maltophilia recorded minimum disease incidence $(4.86 \%)$ and disease intensity $(1.39 \%)$ respectively.
\end{abstract}

\section{Keywords}

F. oxysporum f. sp. phaseoli, PGPR,

Biological management, Beans

\section{Article Info}

Accepted: 04 February 2018 Available Online: 10 March 2018

\section{Introduction}

Common bean (Phaseolus vulgaris L.) belongs to the family Leguminoceae and occupies a premier place among grain legumes in the world including India, where it is locally called as Rajmash (Sharma et al., 1994). The crop originated from Central and
South America, where it was cultivated as early as 6000 BC in Peru and 5000 BC in Mexico and is now being cultivated as a major food crop in many tropical, subtropical and temperate areas of the Americas, Europe, Africa and Asia (Wortmann, 2006). It is produced for both domestic as well as for commercial purpose. The beans contain a 
higher percentage of protein as compared to staple foods such as maize, rice or cassava (Mwale et al., 2008). Dry bean is a good source of protein, essential vitamins and minerals, soluble-fiber starch, and a low fat food (Messina, 1999).

A large number of soil borne and foliar diseases limit the productivity of beans, which affect quality as well as the yield. Fusarium wilt (Fusarium oxysporum (Schlecht.) f. sp. Phaseoli Kendrick and Synder) is one of the most important diseases of common bean worldwide (Schwartz et al., 2005). Root infections cause yellowing and wilt in plants at phonological stages of the blooming and pod-filling. The mild temperatures and high soil moisture and can lead to yield reduction of $80 \%$ in common bean cultivars (Sartorato and Rava 1994; Salgado et al.,. 1996). The destructive nature of this pathogen is prompt to different methods for management of the soil borne diseases of beans including fungicidal treatment of seed and soil. However, fungicide drenches are expensive, impractical and harmful to the environment (Kannan and Jayaraj, 1998). On the other hand, biological control of plant diseases through antagonistic rhizobacteria is an efficient, effective and eco-friendly alternative to the use of synthetic chemicals (Emmert and Handelsman, 1999).

\section{Materials and Methods}

Plant samples showing typical symptoms of yellowing and wilting were collected and bagged separately in perforated paper bags and brought to the laboratory for isolation. From the infected roots of beans bits of approximately 2 to $3 \mathrm{~mm}$ in size were cut from the junction of the diseased and healthy portion of the infected tissue with the help of sterilized blade. These bits were surface sterilized with 0.1 per cent mercuric chloride $\left(\mathrm{HgCl}_{2}\right)$ solution for 30 seconds followed by 3 consecutive washings in sterilized distilled water and then dried on a sterilized blotter paper. Sterilized bits were aseptically transferred onto PDA petriplates and incubated at $25+2^{0} \mathrm{C}$ (Baudoin et al., 1990), and the fungal growth were purified using hyphal tip method (Hansen, 1926). Morphological examinations and cultural characteristics of the isolated fungi were recorded and the observations compared with the standard text (Booth, 1971).

\section{Pathogenicity test}

In order to prove the Koch's postulates, pathogenicity tests were performed on beans cultivar Shalimar French bean-1. The garden soil was sterilized by autoclaving at $15 \mathrm{lb}$ psi for one hour consequently for two days. Pots of 15 inches dia, filled with sterilized soil were inoculated separately with the most commonly associated pathogen i.e. Fusarium oxysporum f. sp. phaseoli @ $5 \mathrm{~g} \mathrm{~kg}^{-1}$ soil. The bean seeds were sown after inoculation of pathogen. The plants were regularly observed for the development of disease symptoms.

\section{Isolation, purification and mass multiplication of rhizobacterial isolates}

For the isolation of rhizobacteria, the soil samples were collected from the rhizosphere of healthy plants and then air dried. Soil thus collected was processed for isolation of bacterial isolates by serial dilution method (Dhingra and Sinclair, 1995). Serial dilutions were prepared using sterilized distilled water. One gm of dried soil was suspended in $9 \mathrm{ml}$ of sterile distilled water and mixed by rolling the tube back and forth between hands to obtain uniform suspension. Subsequently, from the first dilution, $1 \mathrm{ml}$ of the suspension was transferred with the help of a pipette in a test tube containing $9 \mathrm{ml}$ of sterilized distilled water to get the dilution of $10^{-2}$ from which 1 $\mathrm{ml}$ was transferred to another test tube 
containing $9 \mathrm{ml}$ of sterilized distilled water to get a suspension of dilution $10^{-3}$. This process was repeated till the original sample was diluted upto $10^{-7}$. From $10^{-7}$ dilution of $0.1 \mathrm{ml}$ was placed in the centre of pre-poured petriplate containing Nutrient Agar. The suspension was spread uniformly on plates using sterilized L-shaped glass rod and allowed to be absorbed by the medium. The inoculated plates were then incubated in inverted position for 24 hours in BOD incubator at $25+2^{\circ} \mathrm{C}$. Single colonies formed were picked and streaked on pre-poured petriplates containing Nutrient Agar Medium and purified by streak plate method (Koch, 1881). A loop full of bacterial growth was picked from bacterial colonies and continuously streaked on six petriplates containing $20 \mathrm{ml}$ solidified Nutrient agar medium and the petriplates were incubated at $25+2{ }^{0} \mathrm{C}$ for 48 hours. The isolated colonies were subsequently transferred to Nutrient agar medium slants in culture tubes. Pure cultures were taken up for further studies and mass multiplied on Nutrient Agar medium

\section{Evaluation of rhizobacterial isolates against the test pathogens}

The rhizobacterial isolates were tested against the isolated fungal pathogen (Fusarium oxysporum f.sp. phaseoli) by using dual culture technique (Morton and Stroube, 1955). In the dual culture technique $05 \mathrm{~mm}$ mycelial disc of seven days old culture of pathogen was placed separately $01 \mathrm{~cm}$ away from the periphery of the petriplate. On the opposite end a single streak of the bacterial isolate was drawn near the peripheral margin of the plate.

The plates were incubated for 7 days at $28+2^{0} \mathrm{C}$ and the pathogen inhibition was calculated by measuring the radial growth of the pathogen (Wang et al., 2003) and per cent inhibition of mycelial growth of pathogen was accordingly calculated. The isolates which are showing higher biocontrol potential were selected for further studies.

Evaluation of Rhizobacterial strains for disease management and growth promoting properties in vivo

A field experiment was conducted to access the biocontrol of selected bacterial isolates (I1, I-4, I-5, I-20 and I-21) and fungicide (Carbendazim). Bean seeds var, Shalimar French Bean-1 were surface sterilized with 0.1 $\% \mathrm{HgCl}_{2}$ and treated with the suspension of PGPR isolates (Weller and Cook, 1983).

The selected isolates viz., I-1, I-4, I-5, I-20 and I-21 were grown on nutrient agar medium for 48 hours and harvested with sterile distilled water and adjusted to the concentration of $1 \times 10^{8} \mathrm{cfu} \mathrm{ml}^{-1}$ were used for seed treatment and seed biopriming. The bean seed treated with 05 selected PGPR isolates were then observed for disease incidence and disease intensity. Disease intensity was calculated on the basis of percentage of root rot area affected as per the scale described by Bharat and Bhardwaj (2001).

\section{Results and Discussion}

The pathogens was isolated from the infected roots of bean plants. Identification of pathogen was done on the basis of its morphological and cultural characteristics and compared with the standard literature (Table 1). Mycelium was initially colourless and became creamy with age, covering almost entire surface of the petri plates. Fungus was inoculated for further 10 days till sporulation.

Microscopic examination revealed that the mycelium was septate and produced both micro- and macroconidia. Microconidia were single celled, hyline, ovoid and measured 2.5$3.5(3.2) \times 7.0-13.0 \quad(9.5) \mu \mathrm{m}$ in size. Macroconidia were sickle shaped with 2-5 
septate, hyaline measuring 3.0-4.0(3.5) $\times 28$ $40(33.5) \mu \mathrm{m}$ in size.

\section{Pathogenicity test}

Pathogenicity test was conducted in order to satisfy the Koch's postulates.

Surface sterilized bean seeds were sown in pots inoculated with the pathogen whereas, uninoculated pots served as control.

Pots were kept in green house and observation were continuously recorded on appearance of wilt symptoms. It was observed that plants in inoculated pots showed typical wilt symptom whereas, no such symptoms were recorded in case of uninoculated pots.

Pathogen was re-isolated from the artificially inoculated plants and its morphocultural characteristic resembled the one which was used for inoculation. On the basis of these cultural, morphological and pathogenic characteristics the pathogen was identified as Fusarium oxysporum f. sp. phaseoli.

\section{Isolation and identification of rhizoacterial strains}

A total number of 24 rhizobacterial strains were isolated from the rhizosphere of different crops from the experimental field of Faculty of Agriculture SKUAST-K, Wadura.

These rhizobacterial strains were purified by streak plate method. Morphological and cultural characteristics of all isolates were accordingly observed and recorded.

\section{Colony and microscopic characterization}

The colony characteristics of rhizobacterial isolates reveal that, out of 24 rhizobacterial isolates 09 showed light green,0 2 green, 08 cream, 04 white and 01 red colour, 12 were round, non-spreading type whereas, 12 were irregular and spreading type colonies (Table 2).

Among all the rhizobacterial strains, 14 strains showed Gram -ve reaction, whereas, 10 rhizobacterial strains showed Gram +ve reaction. Out of the 24 isolates, 17 were small rods, whereas, 7 isolates were large rods.

\section{Evaluation of rhizobacterial isolates against the pathogen}

The 24 rhizobacterial isolates were tested for their biocontrol potential in vitro against $F$. oxysporum f. sp. phaseoli by using dual culture technique. The data presented in Table 3 reveal that under dual culture with $F$. oxysporum f. sp. phaseoli isolate I-5 exhibited minimum radial growth $(28.00 \mathrm{~mm})$, resulting in inhibition of pathogen by $68.89 \%$ over control. Another isolate I-21 recorded radial growth of $29.63 \mathrm{~mm}$, thereby inhibiting the growth of pathogen by 67.08 per cent over control, followed by the isolate I-1, I-4 and I20 with radial growth of $29.9,32.57$ and 35.37 $\mathrm{mm}$ showing an inhibition of $66.78,63.81$ and 60.7 per cent over control, respectively.

Biochemical and Molecular identification reveals that Isolate I-4 and I-20 is Bacillus cereus, I-5 is Stenotrophomonas maltophilia, isolate I-21 is Pseudomonas sp. Isolate I-1 is identified on the basis of morphocultural and biochemical characterization and identified as Pseudomonas fluorescens.

\section{Effect of Plant Growth Promoting Rhizobacteria on incidence of Fusarium wilt of beans in vivo}

The data on effect of selected PGPR and fungicide carbendazim reveals that all the treatment was statistically superior over the control (Table 4). 
Table.1 Morphological characteristics of Fusarium oxysporum f. sp. phaseoli

\begin{tabular}{|c|c|c|c|c|c|}
\hline $\begin{array}{c}\text { Morphological } \\
\text { stage }\end{array}$ & Colour & Туре & Shape & $\begin{array}{l}\text { Size } \\
(\mu \mathrm{m})\end{array}$ & Septation \\
\hline Mycelium & Hyaline & .... & $\ldots$ & $\begin{array}{c}\text { Hyphal width } \\
1.5-2.0\end{array}$ & Septate \\
\hline \multirow[t]{2}{*}{ Conidia } & \multirow[t]{2}{*}{ Hyaline } & Micro & Ovoid & $\begin{array}{c}2.5-3.5(3.2) \times \\
7.0-13.0(9.5)\end{array}$ & Aseptate \\
\hline & & Macro & Sickle & $\begin{array}{c}3.0-4.0 \\
(3.5) \times 28- \\
40(33.5)\end{array}$ & $\begin{array}{l}\text { Septate } \\
(2-5)\end{array}$ \\
\hline
\end{tabular}

Table.2 Colony and microscopic characteristics of the rhizobacterial isolates

\begin{tabular}{|c|c|c|c|c|c|}
\hline \multirow[t]{2}{*}{ Isolates } & \multicolumn{3}{|c|}{ Colony characters } & \multicolumn{2}{|c|}{ Microscopic characteristics } \\
\hline & Colour & Shape & Nature & Cell shape & Gram reaction \\
\hline $\mathrm{I}-1$ & Light green & Round & Non Spreading & Small Rod & -ve \\
\hline $\mathrm{I}-2$ & Cream & Round & Non Spreading & Small Rod & +ve \\
\hline $\mathrm{I}-3$ & Light Green & Round & Non Spreading & Large Rod & -ve \\
\hline $\mathrm{I}-4$ & Cream & Round & Non Spreading & Small Rod & $+\mathrm{ve}$ \\
\hline $\mathrm{I}-5$ & White & Irregular & Spreading & Small Rod & -ve \\
\hline I-6 & White & Round & Non Spreading & Small Rod & +ve \\
\hline $\mathrm{I}-7$ & Light Green & Round & Non Spreading & Large Rod & -ve \\
\hline $\mathrm{I}-8$ & Green & Round & Non Spreading & Small Rod & -ve \\
\hline I-9 & Light green & Round & Non Spreading & Small Rod & -ve \\
\hline I-10 & Cream & Irregular & Spreading & Large Rod & +ve \\
\hline$\overline{I-11}$ & Light green & Irregular & Spreading & Large Rod & $-\mathrm{ve}$ \\
\hline $\mathrm{I}-12$ & White & Irregular & Spreading & Large Rod & -ve \\
\hline I-13 & Cream & Irregular & Spreading & Small Rod & $+\mathrm{ve}$ \\
\hline I-14 & Cream & Irregular & Spreading & Small Rod & +ve \\
\hline I-15 & Green & Irregular & Spreading & Small Rod & -ve \\
\hline I-16 & White & Irregular & Spreading & Small Rod & +ve \\
\hline $\mathrm{I}-17$ & Cream & Irregular & Spreading & Small Rod & +ve \\
\hline I-18 & Light green & Irregular & Spreading & Small Rod & -ve \\
\hline I-19 & Light green & Round & Non spreading & Large Rod & -ve \\
\hline $\mathrm{I}-20$ & Cream & Irregular & Spreading & Large Rod & +ve \\
\hline I-21 & Red & Round & Non spreading & Small Rod & -ve \\
\hline I-22 & Light green & Round & Non spreading & Small Rod & $-v e$ \\
\hline I-23 & Light green & Round & Non spreading & Small Rod & -ve \\
\hline $\mathrm{I}-24$ & Cream & Irregular & Spreading & Small Rod & $+v e$ \\
\hline
\end{tabular}


Table.3 In vitro evaluation of the rhizobacterial isolates for growth inhibition of Fusarium oxysporum f. sp phaseoli

\begin{tabular}{|c|c|c|}
\hline Isolate & Radial growth (mm) & Inhibition over control (\%) \\
\hline I-1 & 29.9 & 66.78 \\
\hline $\mathrm{I}-2$ & 65.40 & 27.33 \\
\hline $\mathbf{I}-3$ & 63.20 & 29.78 \\
\hline I-4 & 32.57 & 63.81 \\
\hline I-5 & 28.00 & 68.89 \\
\hline I-6 & 64.90 & 27.89 \\
\hline I-7 & 62.93 & 30.08 \\
\hline I-8 & 66.57 & 26.03 \\
\hline I-9 & 54.70 & 39.22 \\
\hline I-10 & 63.93 & 28.97 \\
\hline I-11 & 54.80 & 39.11 \\
\hline I-12 & 57.87 & 35.70 \\
\hline I-13 & 50.27 & 44.14 \\
\hline I-14 & 49.83 & 44.63 \\
\hline I-15 & 57.00 & 36.67 \\
\hline I-16 & 54.93 & 38.97 \\
\hline I-17 & 47.33 & 47.41 \\
\hline I-18 & 63.67 & 29.26 \\
\hline I-19 & 51.47 & 42.81 \\
\hline I-20 & 35.37 & 60.7 \\
\hline I-21 & 29.63 & 67.08 \\
\hline I-22 & 46.97 & 47.81 \\
\hline I-23 & 59.47 & 33.92 \\
\hline I-24 & 57.43 & 36.19 \\
\hline $\mathrm{C}$ & 90.00 & \\
\hline C.D. & 7.147 & \\
\hline $\mathrm{SE}(\mathrm{m})$ & 2.509 & \\
\hline
\end{tabular}


Table.4 Effect of plant growth promoting rhizobacteria on incidence of fusarium wilt of beans in vivo

\begin{tabular}{|l|}
\multicolumn{1}{|c|}{ Treatment } \\
\hline Pseudomonas fluorescens(st) \\
\hline Bacillus cereus 1 (st) \\
\hline Stenotrophomonas maltophilia (st) \\
\hline Bacillus cereus 2 (st) \\
\hline Pseudomonas sp. (st) \\
\hline Pseudomonas fluorescens (bp) \\
\hline Bacillus cereus 1 (bp) \\
\hline Stenotrophomonas maltophilia (bp) \\
\hline Bacillus cereus 2 (bp) \\
\hline Pseudomonas sp. (bp) \\
\hline Carbendazim \\
\hline Control \\
\hline C.D. \\
\hline SE(m) \\
\hline
\end{tabular}

\begin{tabular}{|c|c|c|}
\hline \multicolumn{3}{|c|}{ Disease incidence $\mathbf{( \% )}$} \\
\hline $\mathbf{2 0 1 6}$ & $\mathbf{2 0 1 7}$ & Pooled \\
\hline $6.17(2.78)$ & $7.71(2.84)$ & 6.94 \\
\hline $21.94(4.79)$ & $17.36(4.28)$ & 19.65 \\
\hline $4.43(2.38)$ & $5.29(2.44)$ & 4.86 \\
\hline $29.16(5.49)$ & $25.69(5.16)$ & 27.43 \\
\hline $16.67(4.20)$ & $13.19(3.77)$ & 14.93 \\
\hline $13.89(3.86)$ & $10.41(3.38)$ & 12.15 \\
\hline $31.25(5.68)$ & $28.47(5.42)$ & 29.86 \\
\hline $10.41(3.37)$ & $9.02(3.16)$ & 9.72 \\
\hline $37.50(6.20)$ & $33.33(5.85)$ & 35.42 \\
\hline $25.69(5.15)$ & $21.53(4.73)$ & 23.61 \\
\hline $2.77(1.93)$ & $3.47(2.10)$ & 3.12 \\
\hline $45.83(6.84)$ & $42.36(6.58)$ & 44.10 \\
\hline 0.451 & 0.50 & \\
\hline 0.153 & 0.17 & \\
\hline
\end{tabular}

St- Seed treatment; bp- biopriming

Data is means of three replication

Values in parenthesis are square root transformed values

Table.5 Effect of Plant Growth Promoting Rhizobacteria on intensity of Fusarium wilt of beans in vivo

\begin{tabular}{|l|}
\multicolumn{1}{|c|}{ Treatment } \\
\hline Pseudomonas fluorescens(st) \\
\hline Bacillus cereus 1 (st) \\
\hline Stenotrophomonas maltophilia (st) \\
\hline Bacillus cereus 2 (st) \\
\hline Pseudomonas sp. (st) \\
\hline Pseudomonas fluorescens (bp) \\
\hline Bacillus cereus 1(bp) \\
\hline Stenotrophomonas maltophilia (bp) \\
\hline Bacillus cereus 2 (bp) \\
\hline Pseudomonas sp. (bp) \\
\hline Carbendazim \\
\hline Control \\
\hline C.D. \\
\hline SE(m) \\
\hline
\end{tabular}

\begin{tabular}{|c|c|c|}
\hline \multicolumn{3}{|c|}{ Disease intensity (\%) } \\
\hline $\mathbf{2 0 1 6}$ & $\mathbf{2 0 1 7}$ & Pooled \\
\hline $1.66(1.63)$ & $1.95(1.71)$ & 1.81 \\
\hline $6.53(2.74)$ & $5.28(2.50)$ & 5.91 \\
\hline $1.17(1.52)$ & $1.4(1.58)$ & 1.39 \\
\hline $8.89(3.14)$ & $8.06(3.00)$ & 8.48 \\
\hline $4.86(2.42)$ & $3.89(2.21)$ & 4.38 \\
\hline $3.75(2.18)$ & $2.92(1.98)$ & 3.34 \\
\hline $9.86(3.29)$ & $9.58(3.24)$ & 9.72 \\
\hline $2.64(1.90)$ & $2.50(1.87)$ & 2.57 \\
\hline $11.66(3.56)$ & $10.83(3.43)$ & 11.25 \\
\hline $7.61(2.93)$ & $6.67(2.76)$ & 7.14 \\
\hline $0.69(1.29)$ & $0.97(1.40)$ & 0.83 \\
\hline $21.11(4.69)$ & $16.11(4.13)$ & 18.61 \\
\hline 0.30 & 0.34 & \\
\hline 0.10 & 0.12 & \\
\hline
\end{tabular}

St- Seed treatment; bp- biopriming

Data is means of three replication

Values in parenthesis are square root transformed values 
Seed treatment with carbendazim $(2.77 \%)$ recorded minimum disease incidence, followed by seed treatment with Stenotrophomonas maltophilia (4.43\%), Pseudomonas fluorescens (6.17\%) biopriming with Stenotrophomonas maltophilia $(10.41 \%)$ and biopriming with Pseudomonas fluorescens $(13.89 \%)$ respectively. Maximum was recorded in control with 45.83 per cent.

Data on disease incidence during the year 2017 reveals that all the treatment was superior over the control. Seed treatment with carbendazim $(3.47 \%)$ recorded minimum disease incidence. It is followed by seed treatment with Stenotrophomonas maltophilia (5.29\%), seed treatment by Pseudomonas fluorescens (7.71\%), biopriming by Stenotrophomonas maltophilia (9.02\%) and bipriming by Pseudomonas fluorescens $(10.41 \%)$ respectively. Maximum disease incidence $(42.36 \%)$ was recorded in case of control.

Pooled data on disease incidence reveals that the seed treatment with carbendazim (3.12\%) recorded minimum disease incidence, followed by seed treatment with Stenotrophomonas maltophilia (4.86\%), seed treatment with Pseudomonas fluorescens (6.94\%), biopriming by Stenotrophomonas maltophilia $(9.72 \%)$ and biopriming by Pseudomonas fluorescens (12.15\%) respectively. Maximum disease incidence $(44.10 \%)$ was recorded in control.

Effect of plant growth promoting rhizobacteria on intensity of fusarium wilt of beans in vivo

During the year 2016 and 2017, the effect of selected PGPR and carbendazim treatments on disease intensity was evaluated and the data presented in Table 5. Perusal of the data reveals that during the year 2016, minimum disease intensity was recorded in case of seed treatment with carbendazim $(0.69 \%)$, which is followed by seed treatment with Stenotrophomonas maltophilia (1.17\%), seed treatment with Pseudomonas fluorescens (1.66\%), biopriming with Stenotrophomonas maltophilia (2.64\%) and Pseudomonas fluorescens $(3.75 \%)$ respectively. Highest disease intensity of $21.11 \%$ was recorded in case of control.

Data on disease intensity for the year 2017 reveals that the selected PGPR and carbendazim treatment were significantly superior over the control. Seed treatment with carbendazim recorded minimum disease intensity $(0.97 \%)$, followed by seed treatment with Stenotrophomonas maltophilia (1.4\%), seed treatment with Pseudomonas fluorescens (1.95\%), biopriming with Stenotrophomonas maltophilia $(2.5 \%)$ and Pseudomonas fluorescens $(2.92 \%)$ respectively. Highest disease intensity of 16.11 per cent was recorded in case of control.

Pooled data of disease intensity 2016 and 2017 reveals that all treatment recorded significantly over the control. Seed treatment with carbendazim recorded minimum disease intensity $(0.83 \%)$, followed by seed treatment with Stenotrophomonas maltophilia (1.39\%), seed treatment with Pseudomonas fluorescens (1.81\%), biopriming with Stenotrophomonas maltophilia $(2.57 \%)$ and Pseudomonas fluorescens (3.34\%) respectively. Highest disease intensity of 18.61 per cent was recorded in case of control.

The use of beneficial microorganisms as biocontrol to reduce diseases on various important crops is considered one of the most promising methods in crop management practices. In the present study biological control potential of selected bacterial isolates were studied on bean plants. Pathogen that is found associated with the soil borne diseases of beans is $F$. oxysporum f. sp. phaseoli was 
isolated from the infected roots of bean plants. $F$. oxysporum f. sp. phaseoli produced microconidia and macroconidia. Microconidia were single celled, hyline, ovoid and measured 2.5-3.5(3.2) $\times$ 7.0-13.0 (9.5) $\mu \mathrm{m}$ in size. Macroconidia were sickle shaped with 2 5 septate, hyaline measuring 3.0-4.0(3.5) $\times$ 28-40(33.5) $\mu \mathrm{m}$ in size. Maina, (2017) studied cultural, morphological and pathogenic variability among Fusarium oxysporum f. sp. Phaseoli, where it revealed that isolates showed diverse in terms of cultural, morphological and pathogenic characteristics. The isolates differed in their micro and macroconidia in terms of size and number of septa. The length $\times$ breadth of the microconidia ranged from $8 \times 3.0$ to $10 \times 3.4$ $\mu \mathrm{m}$ with a mean size of $9 \times 3.4 \mu \mathrm{m}$. Macroconidia varied between $28 \times 3.8$ to $42 \times$ $4.2 \mu \mathrm{m}$ with a mean of $37 \times 3.3 \mu \mathrm{m}$. All the isolates had 3 septa macroconidia. The macroconidia of all the isolates were slightly sickle-shaped.

Of the total 24 rhizobacterial isolates, 9 rhizobacterial showed light green, 2 green, 8 cream, 4 white and 1 red colour, whereas, 12 round and non-spreading and 12 irregular and spreading colonies. However, 14 strains showing Gram negative reaction, 10 rhizobacterial strains showing Gram positive reaction. Out of 24 isolates 17 isolates were small rods, whereas, 7 isolates were large rods. The fluorescence under UV light is one of the key characters and the direct detection of fluorescence around the colonies is helpful for the identification of fluorescent pseudomonads (Brown and Lowbury, 1968; Sivasankari and Anandharaj, 2014).

The selected biocontrol isolates (I-1, I-4, I-5, I-20 and I-21) and carbendazim were tested in vivo for disease incidence and intensity. The data on effect of selected PGPR and carbendazim during the year 2016 reveals that Seed treatment with carbendazim $(2.77 \%)$ recorded minimum disease incidence, followed by seed treatment with Stenotrophomonas maltophilia (4.43\%). Disease incidence during the year 2017 reveals that seed treatment with carbendazim $(3.47 \%)$ recorded minimum disease incidence, followed by seed treatment with Stenotrophomonas maltophilia (5.29\%), seed treatment by Pseudomonas fluorescens $(7.71 \%)$. Pooled data on disease incidence reveals that the seed treatment with carbendazim $(3.12 \%)$ recorded minimum disease incidence, followed by seed treatment with Stenotrophomonas maltophilia (4.86\%), seed treatment with Pseudomonas fluorescens $(6.94 \%)$. Perusal of the data reveals that during the year 2016, minimum disease intensity was recorded in case of seed treatment with carbendazim $(0.69 \%)$, which is followed by seed treatment with Stenotrophomonas maltophilia (1.17\%). During the year 2017 seed treatment with carbendazim recorded minimum disease intensity $(0.97 \%)$, followed by seed treatment with Stenotrophomonas maltophilia (1.4\%). Pooled data of disease intensity 2016-17 reveals that seed treatment with carbendazim recorded minimum disease intensity $(0.83 \%)$, followed by seed treatment with Stenotrophomonas maltophilia (1.39\%). Ramamoorthy et al., (2002) found that $P$. fluorescens isolates Pf1 increased plant vigour and consistently reduced the disease incidence under greenhouse conditions and the disease protection was comparable with fungicide carbendazim. Islam et al., 2015 found that PGPR strains applied as a seed treatment significantly reduced disease severity of Phytophthora crown rot on cucumber plants. The fungal antagonists Pseudomonas stutzeri, B. $\quad$ subtilis, B. amyloliquifaciens, and $S$. maltophilia were have been shown to be effective biocontrol agents in prior studies (Dunne et al., 2000; Zhang and Yuen, 2000; Dal Bello et al., 2002; Berg et al., 2005; Islam and Hossain, 2013; Erlacher et 
al., 2014). Competitive root tip colonization by PGPR strains might play an important role in the efficient control of soil-borne diseases.

\section{References}

Baudoin, A. B. A. M., Hooper, G. R., Mathre, D. E. and Carroll, R. B. 1990. Labortory Exercises in Plant Pathology: An instructional kit. The American Phytopathological Society, Scientific publishers, India. 20-27 pp.

Berg, G., Krechel, A., Ditz, M., Sikora, R. A., Ulrich, A. and Hallmann, J. 2005. Endophytic and ectophytic potatoassociated bacterial communities differ in structure and antagonistic function against plant pathogenic fungi. FEMS Microbiol. Ecol 51215-229

Bharat, N. K. and Bhardwaj, L.N. 2001. Interaction between VAM and Dematophorane catrix and their effect on the health of apple seedlings. Indian J. Pl. Path. 19: 47-51.

Booth, C. 1971. The Genus Fusarium.pp. 237. Commonwealth Mycological Institute, Kew, Surrey, England.

Brown, V. I. and Lowbury, E. J. L. 1968. Use of an improved cetrimide agar medium and other culture methods for Pseudomonas aeruginosa. J. Clin. Pathol. 18: 752-756.

Dal-Bello, G. M., Mónaco, C. I. and Simón, M. R. 2002. Biological control of seedling blight of wheat caused by Fusarium graminearum with beneficial rhizosphere microorganisms. World J. Microbiol. Biotechnol. 18:627-636.

Dhingra, O. D. and Sinclair, J. B. 1995. Basic Plant Pathology Methods, pp 434. Lewis Publishers, USA.

Dunne, C., Loccoz, Y. M., de Bruijn, F. J., O'Gara, F. 2000. Overproduction of an inducible extracellular serine protease improves biological control of Pythium ultimum by Stenotrophomonas maltophi lia strain W81. Microbiol. 146 20692078. 10.1099/00221287-146-8-2069.

Emmert, E. A. B, and Handelsman, J 1999. Biocontrol of plant disease: a (Gram-) positive perspective. FEMS Microbiology Letter. 171: 1-9.

Erlacher, A., Cardinale, M., Grosch, R., Grube, M., Berg, G. 2014. The impact of the pathogen Rhizoctonia solani and its beneficial counterpart Bacillus amyloliquefaciens on the indigenous lettuce microbiome. Front. Microbiol 5:175

Hansen, H. N. 1926. A simple method of obtaining single- spore cultures. Science, 64: 384.

Islam, M. T. and Hossain, M. M. 2013. "Biological control of peronosporomycete phytopathogen by bacterial antagonist," in Bacteria in Agrobiology: Disease Management, ed. Maheshwari D. K., editor. (Heidelberg: Springer;), 167-218.

Islam, S., Akanda, A. M., Prova, A., Islam, M. T. and Hossain, M. M. 2015. Isolation and Identification of Plant Growth Promoting Rhizobacteria from Cucumber Rhizosphere and Their Effect on Plant Growth Promotion and Disease Suppression Front Microbiol. Published online doi: 10.3389/fmicb.2015.01360.

Kannan, R. and Jayaraj, J. 1998. Effect of various level of inoculation of Bacillus subtilis on the incidence of damping off of tomato and on the plant growth parameters. Annamalai Uni. Agrl. Res. Ann. 21:24-27.

Koch, R. 1881. Zur Untersuchung von pathogenen organismen. Mitthdungen uusdem Kaiserlichen Gesundbeitsamte 1: 1-48.

Maina, P. K., Wachira, P. M., Okoth, S. A. and Kimenju, J. W. 2017. Cultural, Morphological and Pathogenic Variability among Fusarium oxysporum 
f. sp. phaseoli Causing Wilt in French Bean (Phaseolus vulgaris L.). Journal of Advances in Microbiology 2(4): 1-9

Messina, M. L. 1999. Legumes and soybeans: overview of their nutritional profiles and health effects. Am. J. Clin. Nutr. 70(suppl.):439S-450S. Monsen, E.R. 1988.

Morton, D. J. and Stroube, W. H. 1955. Antagonistic and stimulatory effect of soil microorganism upon Sclerotium rolfsii. Phytopathology 45: 417-420.

Mwale, V.M., Bokosi, J.M. and Masangano, C.M. 2008. Yield Performance of Dwarf Bean Lines Under Researcher Designed Farmer Managed System in Three Bean Agroecological zones of Malawi. African Journal of Biotechnology 7: 2847-2853.

Ramananthan, A., Shanmugam, V., Raguchander, T. and Samiyappan, R. 2002. Induction of systemic resistance in ragi against blast disease by Pseudomonas fluorescens. Annals of Plant Protection Sciences 10: 313-318.

Salgado, M.O., Schwartz, H.F. and Brick, M.A. 1996. Inheritance of resistance to a Colorado race of Fusarium oxysporum f. sp. phaseoli in common beans. Plant Dis 79:279-281

Sartorato, A. and Rava, C.A. 1994. Murcha ou amarelecimento de Fusarium. In: Sartorato A, Rava CA (eds) Principais doenças do feijoeiro comum e seu controle. Embrapa-SPI, Brasília 175$190 \mathrm{pp}$.
Schwartz, H.F., Steadman, J.R., Hall, R., Foster, R.L. 2005. Compendium of bean diseases, 2nd edn. APS Press, St. Paul

Sharma, P. N., Sharma, O. P. and Tyagi, P. D. 1994. Status and distribution of bean anthracnose $\mathrm{n}$ Himachal Pradesh. Himachal Pradesh Journal of Agriculture Research 20: 91-96.

Sivasankari, B. and Anandharaj, M. 2014. Isolation and Molecular Characterization of Potential Plant Growth Promoting Bacillus cereus GGBSTD1 and Pseudomonas spp. GGBSTD3 from Vermisources Hindawi Publishing Corporation Advances in Agriculture Volume 2014, Article ID 248591, 13 pages http://dx.doi.org/10. $1155 / 2014 / 248591$

Weller, D. M. and Cook, R. J. 1983. Suppression of take all of wheat by seed treatment with fluorescent pseudomonas. Phytopathology, 73: 463469.

Wortmann, C. S. 2006. Phaseolus vulgaris L. (common bean). Record from PROTA4U. Brink, M. \& Belay, G. (Editors). PROTA (Plant Resources of Tropical Africa / Ressources végétales de l'Afrique tropicale), Wageningen, Netherlands

Zhang, Z. and Yuen, G. Y. 2000. The role of chitinase production by Stenotrophomonas maltophilia strain C3 in biological control of Bipolaris sorokiniana. Phytopathology 90:384389.

\section{How to cite this article:}

Stanzin Dorjey, T.A. Shah, N.A. Bhat, P.A. Sofi, Z.A. Baba and Chatoo, M.A. 2018. Evaluation of PGPR Isolates for the Management of Beans Wilt Caused by Fusarium oxysporum f. sp. phaseoli. Int.J.Curr.Microbiol.App.Sci. 7(03): 355-365. doi: https://doi.org/10.20546/ijcmas.2018.703.041 